\title{
Identifying The Working Process Of Automatic Fish Feed Tool Based On Arduino Uno
}

\author{
Ertie Nur Hartiwati \\ Faculty of Computer Science and Information Technology, Gunadarma University \\ ${ }^{*}$ Corresponding author: \\ Email: ertie@staff.gunadarma.ac.id
}

\begin{abstract}
.
This Arduino-Based Automatic Fish Feeding Tool is a tool that serves to make it easier to care for fish in the aquarium, especially the feeding. The purpose of making this automatic fish feed tool is to explain about the automatic fish feed tool. The ability of this tool is that it can provide feed automatically with the given time plan is feeding 2 times a day and for the amount of feed dose adjusted to the number of servo motor rotations, namely 1 rotation of $150^{\circ}$, resulting in a feed dose of 10 Grams. With the working method using the Arduino IDE application and with the Arduino Uno working system, a command coding is given which is combined with the Uno shield board then jumper to the RTC DS3231 so that it can show the time very accurately and update the time data in real time.
\end{abstract}

Keywords: Arduino Uno, RTC Sensor, LCD, Automatic fish feed, Servo Machine, Acrylic

\section{INTRODUCTION}

Ornamental fish aquariums serve as room decorations / places for fish which are very much favored by fish hobbyists. Aquariums are useful for beautifying the aesthetics of a room. In the aquarium, of course, contains water and ornamental fish. for hobbyists who keep Chana fish size $7 \mathrm{~cm}$ only requires a large aquarium Length $=35 \mathrm{~cm}$, Height $=25 \mathrm{~cm}$ and Width $=20 \mathrm{~cm}$. It is sufficient so that the fish can move freely with the number of territorial fish 1 in one aquarium. In raising fish there is work that must be done every day, one of the important things in maintaining fish is feeding fish. In previous research, there was an automatic feeding device in aquaculture ponds whose size and users were devoted to ponds.

The system in feeding fish still relies on human resources for feeding, which is still manual in giving it by using hands by sowing it. The application of this system still has shortcomings, namely the frequent occurrence of late or inconsistent feeding. So the current activity is being developed all electronically by using data as a command, one of which is a way that can be done to overcome this problem is to create a tool that can feed the fish in the aquarium automatically.One technology that can be used is automation in fish feeding. In this study, an automation design for fish feeding equipment was developed using the Arduino Uno R3 microcontroller by giving time control to the specified RTC (real time clock) time sensor. To improve consistent and timely feeding. With this tool, it is hoped that it can help human work, and become a tool that can be useful for automatic feeders for every pet feeding at home with the type of feed in the form of small pellets.

\section{LITERATURE REVIEW}

This Arduino-Based Automatic Fish Feeding Tool is to make it easier to care for fish in the aquarium, especially in feeding, so that when fish keepers are busy or have problems and when leaving fish in their aquariums for a long time, the fish will stay awake in the feeding process. With the time plan given is feeding 2 times a day and for the amount of feed dose adjusted to the needs of the number / size of Chana fish in the aquarium.

\subsubsection{Components of automatic fish feed tool}

As for the components contained in the automatic fish feed tool, namely:

a. Arduino Uno 
Arduino Uno is a hardware output from Arduino Italy in the form of a minimum system using the Atmega 328 microcontroller, Arduino has 14 digital pins of which 6 pins can be used as pulse modulo output or and 6 analog inputs.

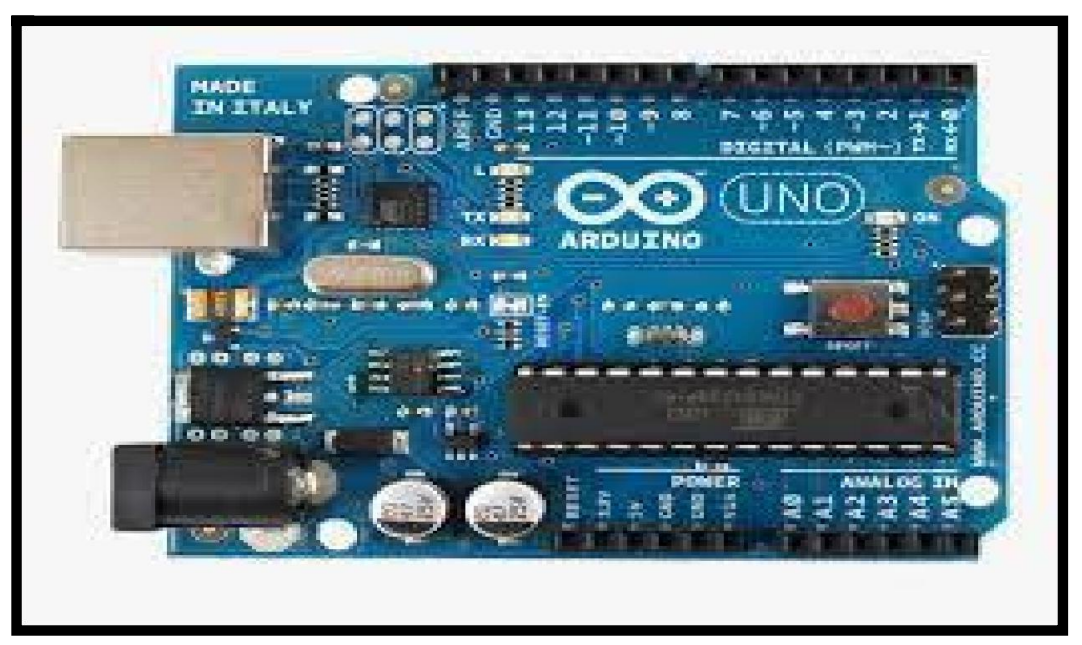

\section{b. UNO shieldboard}

serves as a help board to replace the bread board, this board is quite simple just to be inserted into the arduino uno board like a tool for the arduino itself which can be multifunctional in one board.

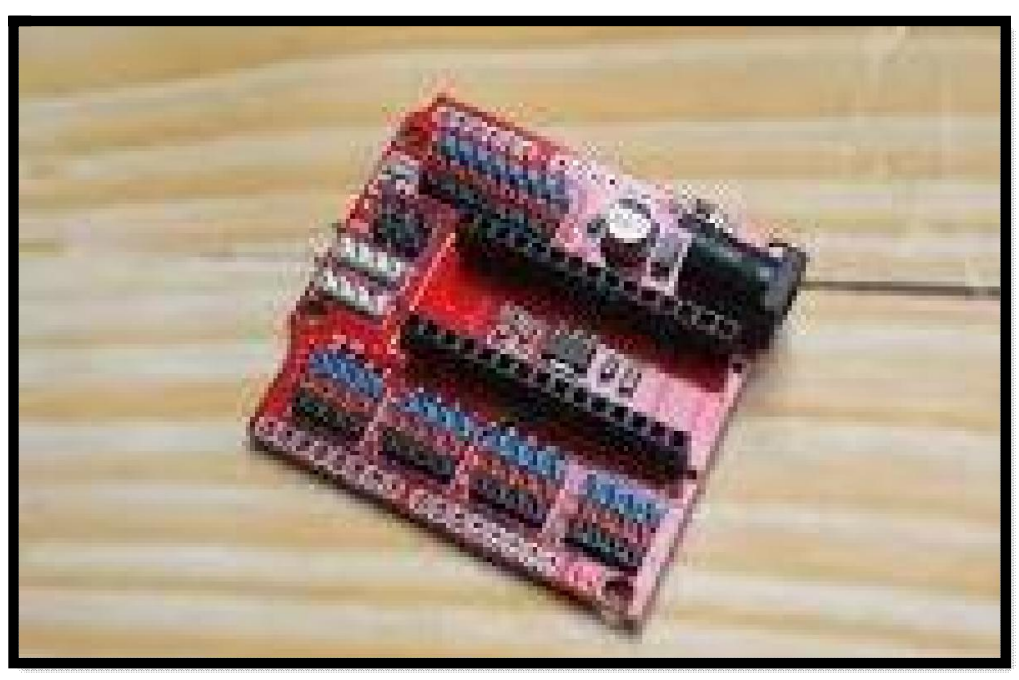

RTC (real time clock) DS3231 is an electronic clock chip that can show the time very accurately and can store and update time data in real time.

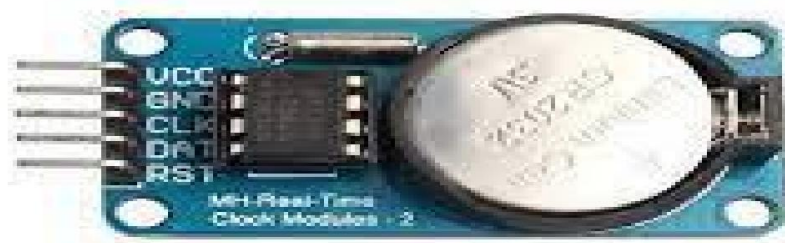




\section{c. $L C D$}

LCD (liquid crystal display) Serves as a display used in automatic fish feed tools.

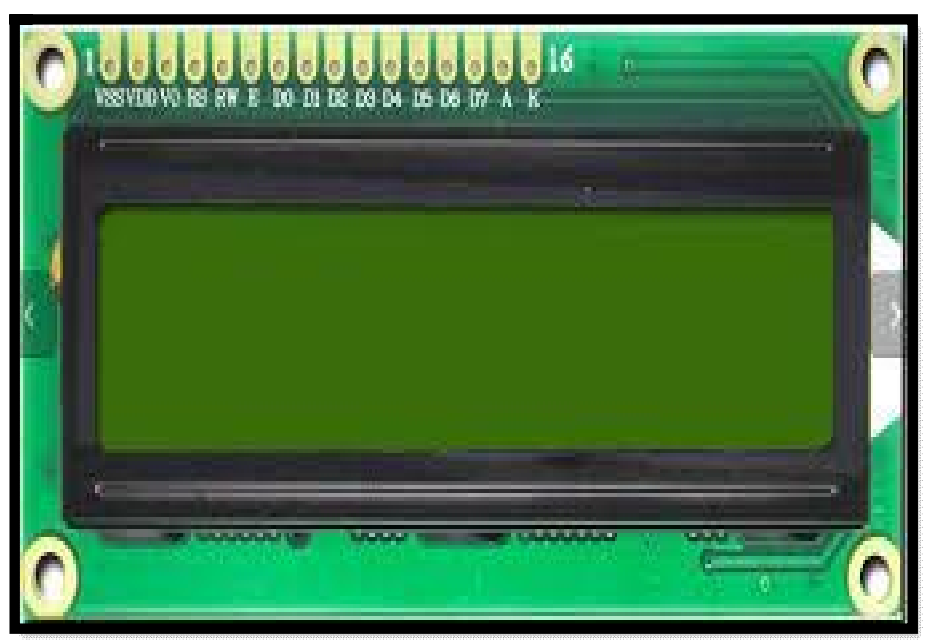

\section{d. Servo Motor.}

The SG90 Servo Motor functions as a device that will move the bottle containing the feed and is rotated by the servo so that the feed falls through the available holes.

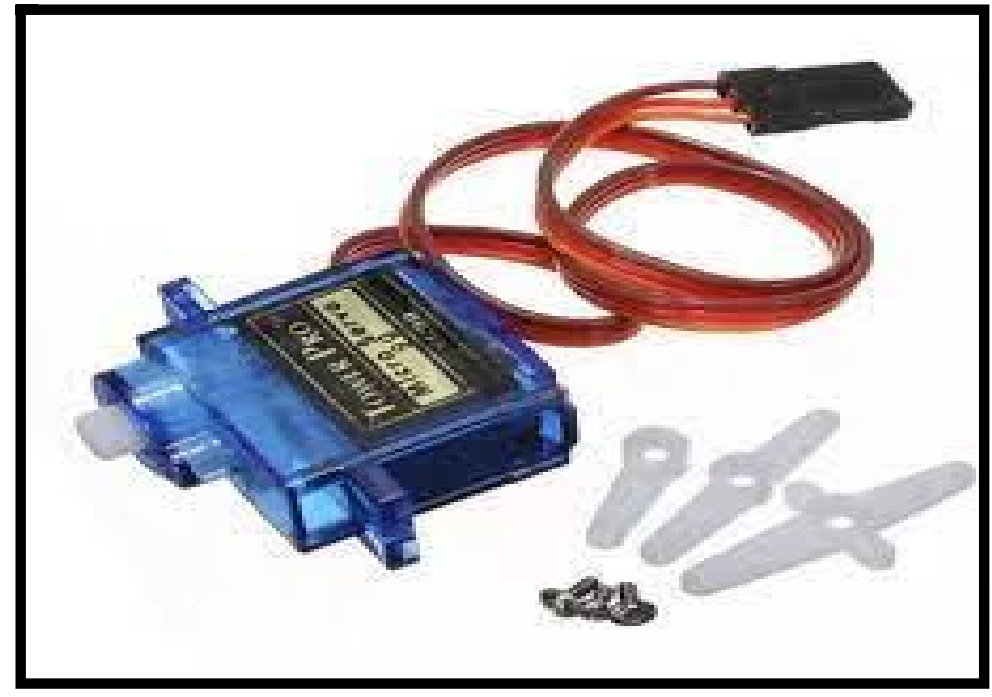

e. Adapter

The adapter serves as a power supply input connector.

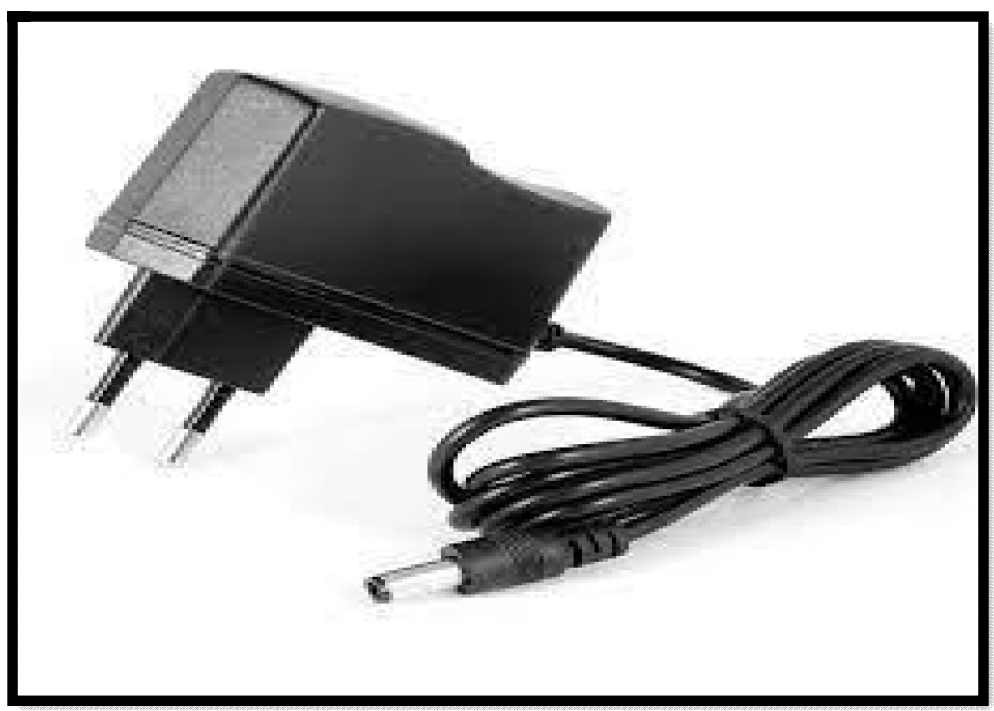




\section{RESEARCH METHOD}

\section{Automatic Fish Feed Tool Flowchart}

Below is a flowchart of the stages in making the workflow of an automatic fish feed tool:

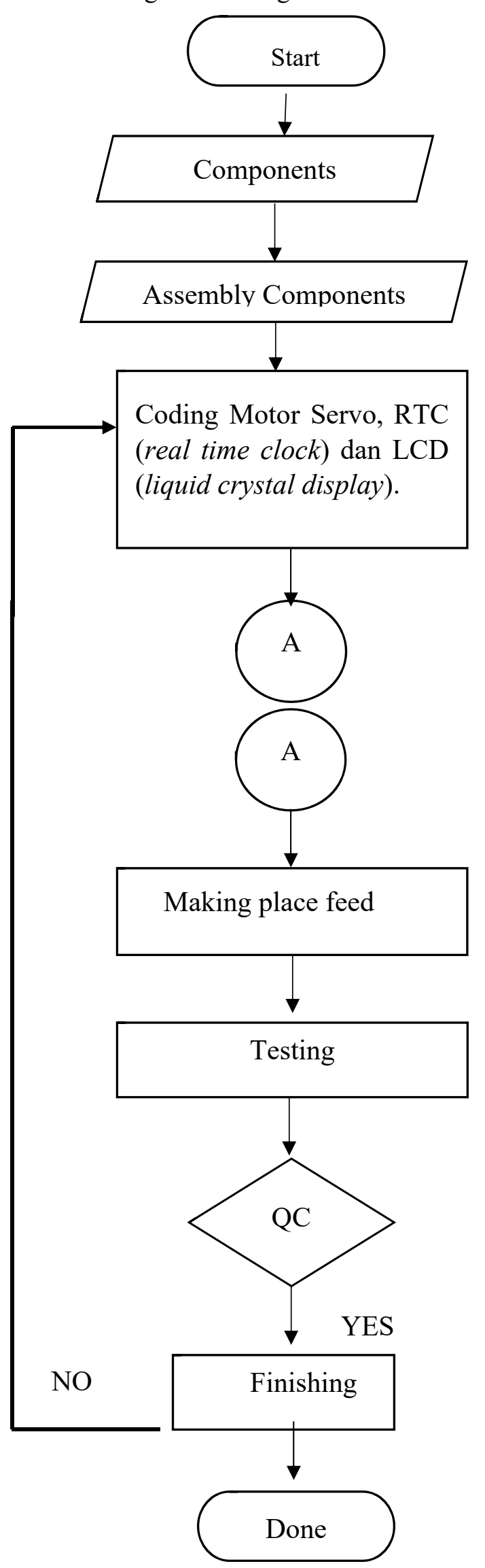




\section{RESULTS AND DISCUSSIONS}

Servo Motor Coding, RTC (real time clock) and LCD (liquid crystal display).

In this process, the commands for servo motors, RTC sensors and LCD are given and the functions entered are:

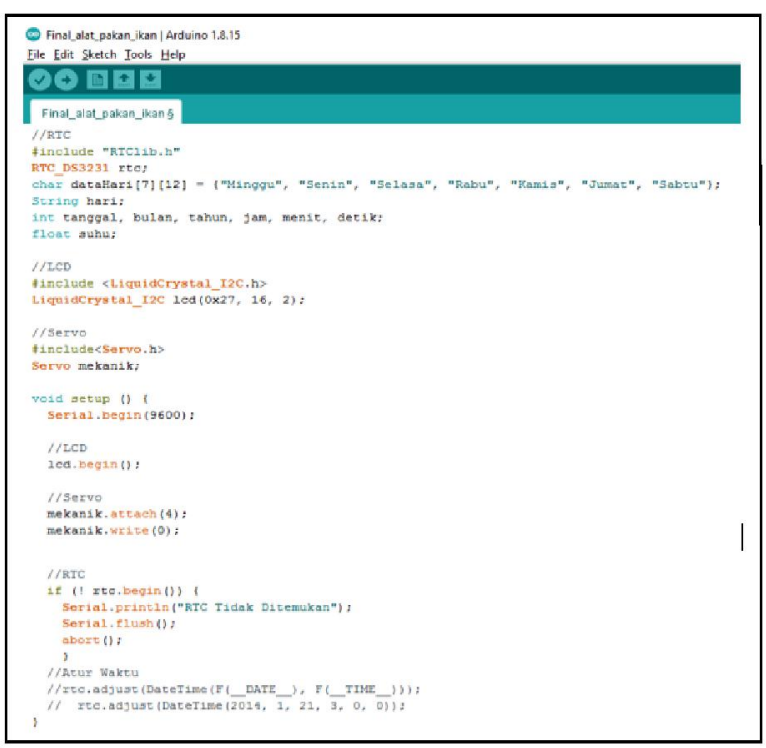

Include

in this data there is \#include which means the intended input is RTC, LCD and Servo. And there are also char, string, int, float functions that are intended as input/output data from RTC.

\section{Void Setup}

This is where the Arduino program starts, which is at the beginning, or when power is on. There is serial.begin (9600) this is the data transfer rate, mechanic.attach is the mounting position on pin 4, and Mekanik.write is the condition for returning to the starting point, namely 0 on the servo motor. For RTC will activate the time / day.

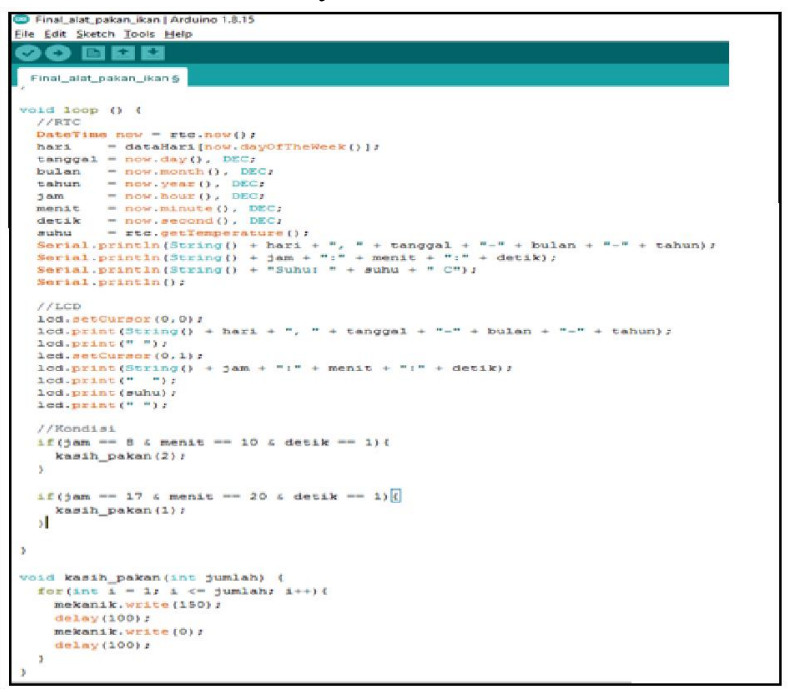

\section{Void Loop}

(// RTC) This command will run its job, which is to provide day, date, month, year, hour, minute, second and temperature data. (// LCD) this command will display the command from lcd.print given by Serial.printin on the RTC in the form of day, date, month, year, hour, minute, second and temperature. The function of (// condition) above is program logic commands to set the time when the servo motor will move. Then (mechanic.write (150)) it is a command for the servo motor to rotate $150^{\circ}$ after moving it will delay(100) wait 100 milliseconds and the servo will return to condition 0. 


\section{CONSLUSION}

Done here, all components and automatic fish feed tools are ready and can be operated.

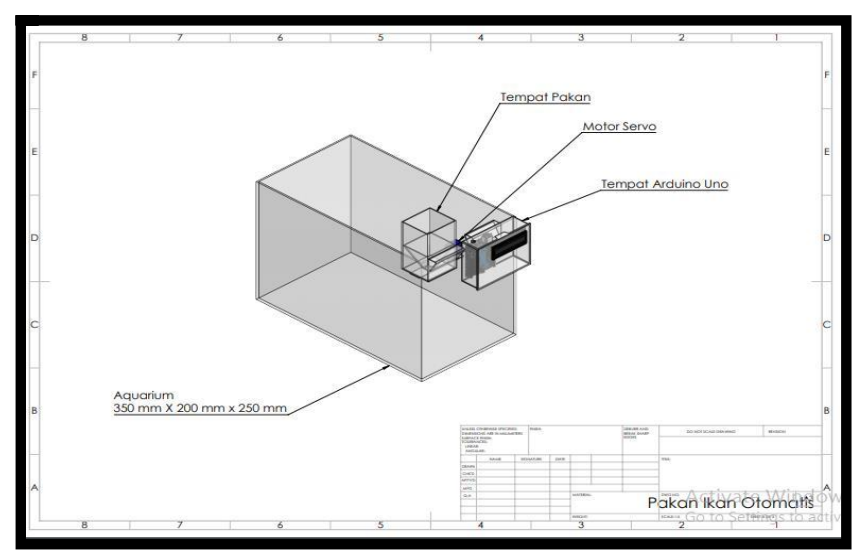

\section{REFERENCES}

[1] Andik Giyartono, Priandhana Edy Kreshna . (2015). "Aplikasi Android Pengendali Lampu Rumah Berbasis Mikrokontroler ATMEGA328". jakarta

[2] Rahmat Faizal, Muh. Rian Eka Duri. (2020). "Perancangan Smart Light Dengan Memanfaatkan Mikrokontroler Arduino Untuk Menyalakan / Mematikan Lampu Berbasis Perintah Suara Via Android". Makasar

[3] Nurmasyitah, (2017). "Penentuan Konstanta Dielektrik Akrilik". Jurnal Jeumpa

[4] Djuandi F. (2011). Pengenalan Arduino. E-Book. Www.Tobuku, 1-24

[5] Kadir, A. (2012). Panduan Praktis Memperlajari Aplikasi Mikrokontroler Dan Pemrogramannya Menggunakan Arduino. Yogyakarta: Andi.

[6] Sainsmart. (2015). Datasheet LCD 16X2, Lenexa, Kansas, Amerika Serikat

[7] Sainsmart. (2015). Datasheet Arduino uno, Lenexa, Kansas, Amerika Serikat

[8] Moh Handigar, Hafidzh Randy.(2019) "Pembangunan Pemakan Ikan Otomatis Menggunakan Arduino" Yogyakarta

[9] R. Suharmon, "Perancangan Alat Pemberi Makan Ikan Otomatis dan Pemantau Keadaan Akuarium Berabasis Mikrokontroler Atmega8535”, Teknik Elektro, Medan, 2014. 